Article

\title{
Universities, Sustainability, and Neoliberalism: Contradictions of the Climate Emergency Declarations
}

\author{
Kirstie O’Neill * and Charlotte Sinden \\ School of Geography and Planning, Cardiff University, Cardiff, CF10 3AT, UK; E-Mails: oneillk1@cardiff.ac.uk (K.O.), \\ sindenc@cardiff.ac.uk (C.S.) \\ * Corresponding author
}

Submitted: 25 November 2020 | Accepted: 3 March 2021 | Published: 28 April 2021

\begin{abstract}
UK universities have been successively declaring a climate emergency, following the University of Bristol's lead in 2019. Universities are key actors in climate change education, and potentially progressive organisations researching, teaching and implementing low carbon futures. Using universities' sustainability strategies, we present a secondary analysis identifying neoliberalism's significant role in influencing universities' sustainability policies and practices. This plays out through university boosterism where universities use their sustainability work to claim sustainability leadership, representing a form of sustainability capital to attract funding and potential students. Furthermore, we suggest a cognitive-practice gap exists between those researching sustainability and those implementing sustainability in universities. Thus, we conclude that there are inherent tensions in universities' sustainability governance, with universities embodying contradictory sustainability discourses and advancing a form of green capitalism. Entrenched neoliberal ideologies present challenges for those declaring a climate emergency and how such declarations are subsequently operationalised.
\end{abstract}

\section{Keywords}

climate change; climate emergency; neoliberalism; sustainability; United Kingdom; universities

\section{Issue}

This article is part of the issue "Is There a New Climate Politics? Emergency, Engagement and Justice" edited by Anna R. Davies (Trinity College Dublin, Ireland), Stephan Hügel (Trinity College Dublin, Ireland) and Vanesa Castán Broto (University of Sheffield, UK).

(C) 2021 by the authors; licensee Cogitatio (Lisbon, Portugal). This article is licensed under a Creative Commons Attribution 4.0 International License (CC BY).

\section{Introduction}

The climate emergency notion, although not new, gained rapid ground during 2019, following statements from the IPCC, the global youth climate strikes, and a growing number of climate-related events such as the extensive and devastating wild-fires in Australia (Gibbs, in press). A wide range of organisations have made declarations, yet for Hulme (2019) the climate emergency declarations are reductionist. UNEP (2018, p. vx) stated that 2020 is the latest year when emissions should peak to meet the Paris Agreement temperature targets. The IPCC projections indicate the need for socioeconomic transformation (Gills \& Morgan, 2020, p. 894), yet there is little sign of emissions abating nor the neces- sary institutional change (Dobson, 2019; Gills \& Morgan, 2020). The high-carbon conjuncture, now known as the Anthropocene, provides a strong rationale for such institutional change. Universities are one actor amongst many that have declared a climate emergency, albeit not all universities have made such climate emergency declarations. However, they are frequently seen as having moral responsibility (Croog, 2016) to drive sustainability transitions (Lightfoot, 2019; Ramísio, Pinto, Gouveia, Costa, \& Arezes, 2019). The educational role of universities in influencing future generations' sustainability practices is seen as critical, and university campuses represent opportunities for greening. Many universities have committed to sustainability strategies, with some developing sustainability centres, and other organisations 
promote sustainability within the sector (e.g., Green Gown Awards, Students Organising for Sustainability, and the Sustainability Exchange).

In this article, we present our secondary analysis of university sustainability strategies, as well as media and sector-specific discussions of the climate emergency. As Blythe et al. (2018) observe, the language used in internationally agreed goals and policies shapes the discursive context for sustainable development agendas, including sustainability research, policy, funding, and interventions (see also Hatzisavvidou, 2020). Discursive frameworks are adopted and interpreted by a range of actors, which guide (or limit) the key foci and the types of action deemed appropriate for addressing sustainable development and the climate emergency. The sustainability discourses universities employ reveals how they currently define and practice sustainability and offers insights into future actions arising from their declarations.

Gormally, O’Neill, Hazas, Bates, and Friday (2019) argue that the neoliberalisation of the university sector creates points of tension in relation to sustainability. The recent climate emergency declarations have emerged within this neoliberal context, which is potentially problematic given that neoliberalism works against sustainability more widely (Hatzisavvidou, 2020). Climate change represents a potential impediment to further capital accumulation, but the creation of new markets centred around clean technology, electric vehicles and efficiency savings purportedly address this, whilst remaining firmly within continued neoliberal capitalism (Ciplet \& Roberts, 2017). We argue that universities work in ways compatible with the notion of a socio-ecological fix (Chambers, 2020) whereby climate change represents the latest capitalist crisis in need of a fix. Incremental responses to climate change will not deliver urgently needed transformative action (Bulletin of the Atomic Scientists, 2020). This article contributes to an emerging body of literature on climate emergency declarations and makes important observations regarding neoliberalism and potential sustainable transformations.

The next section reviews the relevant literature, we then discuss our methods and data sources. In section four we present our findings, before offering some conclusions and avenues for future research.

\section{The Climate Emergency and Neoliberalism}

In the global North, many universities have engaged with sustainability and are seen as change agents, offering new ideas to help address significant global environmental problems. Enacting a low carbon transition raises questions for institutions about how they can reorient their operations to meet such environmental objectives (cf. Dobson, 2019). As Dobson (2019) notes, the very institutions and organisations that are perceived as being able to facilitate transformation may be stumbling blocks. The path to decarbonisation is far from straightforward (Jänicke, 2008), and there can be many diver- sions and distractions. The neoliberalisation of both the UK university sector and responses to climate change present distractions and challenges, as agendas of internationalisation and research metrics continue to promote unsustainable practices (see Whitmarsh, Capstick, Moore, Jana, \& Qu, 2020).

There are ongoing debates regarding the extent to which sustainability should be embedded into universities' routine activities. These discussions relate to whether sustainability should feature in research and teaching across all disciplines and guide the daily operation of the institution and infrastructural settings (Disterheft, Caeiro, Azeiteiro, \& Leal Filho, 2013; Lozano, 2006). There are multiple incentives including benchmarking schemes (e.g., People and Planet Index), certification schemes (e.g., Food for Life), and awards and prizes (e.g., Green Gown awards) which offer financial and reputational benefits in recognition of sustainability achievements. These are often used to showcase an institution's (green) identity to prospective students, researchers, academics and funders, enabling institutions to cultivate a 'sustainable' image.

Research-intensive universities have been identified as significant contributors to sector carbon emissions: The 20 research-intensive institutions that make up the Russell Group contribute to over half of the UK's universities' carbon emissions (Wadud, Royston, \& Selby, 2019). Universities are simultaneously viewed as being uniquely equipped for practicing sustainability and leading the sustainability movement-indeed, it has been suggested that they have a moral duty to reach the next generation of influencers and leaders (Croog, 2016; Disterheft et al., 2013). Renouf et al. (2019) contend that with the scale and severity of the climate crisis, universities should prepare staff and students for living with a new 'normal' of a changing climate, which will fundamentally reshape all forms of work and life. For them, universities owe it to their students to be at the forefront of addressing the ecological and climate emergency and should act now given their significant carbon and environmental footprints (see also Hoolohan et al., 2021). Moreover, graduating students have the potential to disrupt business-as-usual to create a more hopeful Anthropocene (cf. Buck, 2015).

There is symbolic and performative importance in declaring a climate emergency, but the declarations have implications for action. However, how universities (and other organisations) will be held to account for meeting/failing to meet their goals is yet to unfold. Gills and Morgan (2020) reflect that despite multiple global climate agreements, emissions have increased. With international agreements such as the Paris Agreement reliant on voluntary agreements that have yet to demonstrate their effectiveness (Ciplet \& Roberts, 2017), how can the climate emergency declarations signal a new and more radical political future? Researchers argue that we need new and creative ways of living with the world that enable "alternative framings of the actual, the possible 
and the desirable" (Castree, 2015, p. 12) to be explored and pursued, yet these ideas remain disconnected from the ways many universities are managed. Radical ideas, such as complete systems change, are promoted beyond academia too, for instance, Greta Thunberg (2020) wrote to European heads of state demanding climate action: "Our current system is not broken-the system is doing exactly what it's supposed and designed to be doing. It can no longer be fixed. We need a new system."

Scholars focusing on the 'climate emergency' frequently express that we need to "articulate a no-carbon, radically democratic alternative" (Cohen, 2020, p. 52), and that universities need to be part of this, moving beyond capitalist, neoliberal, business-as-usual practices. However, Gills and Morgan (2020) suggest that, in many organisations, there is little evidence of appropriate action beyond recognising the climate emergency. In January 2020, The Bulletin of the Atomic Scientists (2020) wrote to leaders and citizens of the world emphasising the climate emergency: They specifically focused on the inadequacy of government policies and actions that fall short and are incommensurate with the scale of the climate emergency. Such inaction has worsened the climate emergency. Thus, many now recognise that crises cannot be solved within existing, dominant, typically market-driven structures, but instead require a system transformation towards decarbonisation.

\subsection{The Neoliberal Institution}

Bergland (2018) argues that 'academic capitalism' (Slaughter \& Leslie, 1997) has seen universities shift from being public goods to companies producing knowledge, delivering key skills of competitiveness and entrepreneurialism. Students are thus reconceptualised as atomised individuals buying an education from the market, while universities compete for students, funding, and league table positions. There is growing recognition that the "system of capital accumulation with its commitment to material growth of economies" (Gills \& Morgan, 2020, p. 897) represents a major barrier, exacerbating environmental problems whilst working to preserve the status quo. Gills and Morgan thus suggest that degrowth must be repositioned as responsible, not radical. This would necessitate major interventions in the neoliberal economies that we have become conditioned to accept as natural and enduring (Feola, 2020), yet Gills and Morgan (2020) see degrowth as the only realistic option. However, as Cupples and Pawson (2012, p. 16) note, neoliberalism is not "monolithic, inevitable and stable," thus there is potential for the disruptive promise of climate emergency declarations.

It is important to reflect on the discourse of an 'emergency' or 'disaster,' and what this may suggest is possible as a result of the declarations-declarations are not an end point, but should rather signal a new beginning, yet even the language of 'climate emergency' can foreclose some possibilities whilst opening others.
As Cupples (2012) suggests, 'disasters' or 'emergencies' have potential to cause destruction but also offer space for transformative political change. However, the a priori political and social structures shape both the scale of the disaster and the futures made possible post-disaster (Cupples, 2012, p. 337). She points to the dangers of neoliberal economic policies for recovery from hurricanes and applies this to the context of the neoliberal university. Anderson, Grove, Rickards, and Kearnes (2020, p. 623) discuss the discursive work that the term 'emergency' does in the advent and (re)production of existing and new forms, practices, and relations of power. They point to research that focuses on what the act of formal declaration enables, and the kinds of action subsequently deemed possible. Another body of research problematises the 'state of emergency' by viewing 'emergency' as a technique of liberal rule. Thus, governing through emergencies deploys mundane techniques that work to enable the return of the non-emergency (neoliberal) everyday (Anderson et al., 2020, p. 624). In such framings, the idea of a climate emergency is conceptualised as a problem with a (human) solution, often articulated in geo-engineering approaches associated with the Good Anthropocene (Wright, Nyberg, Rickards, \& Freund, 2018), and which may then preclude more radical outcomes (e.g., degrowth) and longer temporal perspectives (e.g., Indigenous knowledge; see Kopnina, 2020). As Jackson (2020) suggests, emergency responses can lack reflexivity, a reflexivity that is greatly needed when dominant biophysical approaches to the Anthropocene are framed in Crutzen and Schwägerl's (2011) terms: "We...decide what nature is and what it will be. To master this huge shift, we must change the way we perceive ourselves and our role in the world."

Problematically, the term 'emergency' can be employed to signify an event that is recognised, but which can, nevertheless, be resolved by actions taken to reach a point of closure. However, understanding the climate emergency in this way can be misleading given that climate change is already being experienced (Madden, 2019), and the already existing and altered atmospheric greenhouse gas concentrations will have irreversible and long-lasting effects (Dalby, 2019). Climate change is a global, long-running emergency 'event,' with temporally and spatially variegated impacts, requiring materially different forms of governance. Moreover, decarbonisation processes will have global and uneven effects. As a result, what the 'emergency' can address is the extent to which the future follows different scenarios, ones of high, low or no growth and associated greenhouse gas emissions, but these futures may be co-opted to preserve neoliberalism and economic growth. Thus, thinking about the terms 'disaster' and 'emergency' gives rise to how they might be governed, what governance techniques are required, the types of solutions made possible, and how multiple actors can be enrolled to both perceive the emergency and act on it. That climate emergency declarations have been 'heard' offers hope 
of forthcoming action and change, as well as greenhouse gas emission reductions, but the important work is yet to come in how the state and other institutions respond. This hope may, of course, be misplaced false hope, but as Osborne (2019, p. 148) states: "There are still...possible shared futures...and some of them are worth having." We can discern multiple ecological, climatic, economic and social emergencies existing in tandem, yet each operating on different temporal registers affecting different people and places unevenly. A key challenge is how to create spaces of resistance and political intervention in response to the climate emergency declarations. How can the climate emergency be differentiated from other emergencies, even when anthropogenic climate change is a critical and omnipresent emergency framing all others (Huijbens, 2021)? Given other events in 2020 (e.g., Black Lives Matter), how might climate emergency declarations work to benefit poorer and Indigenous or ethnic communities rather than legitimising actions to their detriment (Goh, 2019; Whyte, 2020)-or what Hulme (2019) calls justifying the suspension of 'normal' politics? It is important to attend to the discourses that are embedded in climate emergency declarations and discern the voices that may remain unheard.

In the analysis that follows, we discuss how the neoliberalisation of UK universities affects how they enact sustainability, leading to 'solutions' that are framed in terms of, and which appeal to, market ideologies. The language, and the initiatives, follow trends such as cleantech (see Goldstein, 2018) where ideas that were once considered peripheral have become folded into the neoliberal project yet emptied of their radical potential. We explore how the act of making the climate emergency declarations by institutions such as governments, businesses, and universities may involve a reconfiguration of what such declarations mean.

\section{Methods}

This article draws on secondary research focusing on UK universities. We selected a representative sample of 17 universities across England, Northern Ireland, Scotland, and Wales, whose sustainability strategies were analysed. In addition to geographical representation, we accounted for characteristics including: Russell Group membership, university types such as 'Redbrick,' 1960s, and post-1992 universities, different sized student populations, as well as universities with sustainability champions. We also examined whether respective local government bodies had declared climate emergencies, and universities' sustainability league table positions (see Table 1 for an overview).

Complementing this, some universities are involved in wider sustainability projects-e.g., SOAS works

Table 1. Characteristics of the sample.

\begin{tabular}{|c|c|c|c|c|c|c|c|c|c|c|c|c|c|c|c|c|c|c|}
\hline \multirow[b]{2}{*}{ University } & \multirow[b]{2}{*}{ 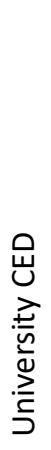 } & \multirow[b]{2}{*}{ 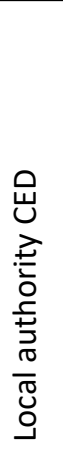 } & \multirow[b]{2}{*}{ 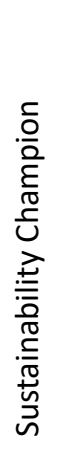 } & \multirow[b]{2}{*}{ 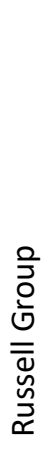 } & \multirow[b]{2}{*}{ 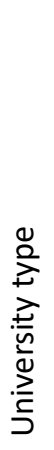 } & \multirow[b]{2}{*}{ 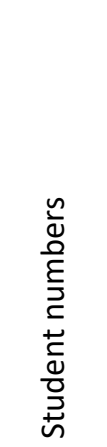 } & \multirow[b]{2}{*}{ 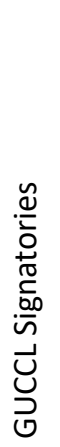 } & \multirow[b]{2}{*}{ 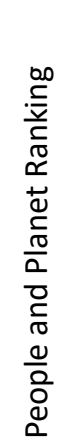 } & \multirow[b]{2}{*}{ 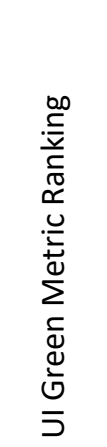 } & \multicolumn{9}{|c|}{ Priority Themes } \\
\hline & & & & & & & & & & 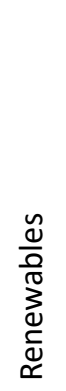 & 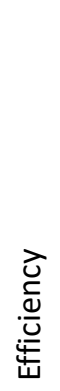 & $\begin{array}{l}\bar{D} \\
\stackrel{D}{\equiv}\end{array}$ & 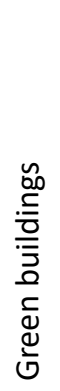 & 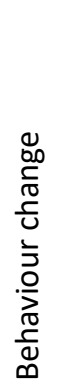 & $\begin{array}{l}\text { 몬 } \\
\text { 인 }\end{array}$ & 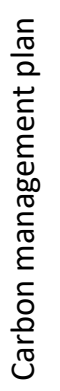 & 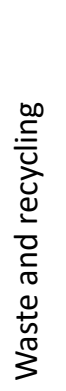 & 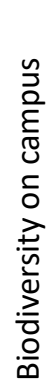 \\
\hline Bristol & $\checkmark$ & $\checkmark$ & $\checkmark$ & $\checkmark$ & 2 & 22278 & $\checkmark$ & 11 & & $\checkmark$ & $\checkmark$ & $\checkmark$ & $\checkmark$ & $\checkmark$ & $\checkmark$ & & & $\checkmark$ \\
\hline Cardiff & $\checkmark$ & $\checkmark$ & $\checkmark$ & $\checkmark$ & 2 & 30180 & $\checkmark$ & 46 & & & $\checkmark$ & $\checkmark$ & & $\checkmark$ & & $\checkmark$ & $\checkmark$ & $\checkmark$ \\
\hline Edinburgh & $\checkmark$ & & $\checkmark$ & $\checkmark$ & 1 & 33609 & $\checkmark$ & 38 & & $\checkmark$ & $\checkmark$ & $\checkmark$ & $\checkmark$ & $\checkmark$ & $\checkmark$ & $\checkmark$ & & $\checkmark$ \\
\hline Lancaster & & $\checkmark$ & & & 3 & 13336 & $\checkmark$ & 91 & & $\checkmark$ & $\checkmark$ & $\checkmark$ & & $\checkmark$ & & $\checkmark$ & $\checkmark$ & $\checkmark$ \\
\hline LSE & & & $\checkmark$ & $\checkmark$ & & 11960 & & 13 & & $\checkmark$ & $\checkmark$ & $\checkmark$ & $\checkmark$ & $\checkmark$ & $\checkmark$ & $\checkmark$ & $\checkmark$ & $\checkmark$ \\
\hline Nottingham Trent & & $\checkmark$ & $\checkmark$ & & 4 & 33255 & & 3 & UK \#3 & $\checkmark$ & $\checkmark$ & $\checkmark$ & $\checkmark$ & & $\checkmark$ & $\checkmark$ & $\checkmark$ & $\checkmark$ \\
\hline Oxford & & $\checkmark$ & $\checkmark$ & $\checkmark$ & 1 & 23975 & & 45 & UK \#1 & $\checkmark$ & $\checkmark$ & & $\checkmark$ & & $\checkmark$ & $\checkmark$ & $\checkmark$ & $\checkmark$ \\
\hline Queens Belfast & & $\checkmark$ & $\checkmark$ & $\checkmark$ & 2 & 24695 & & 103 & & $\checkmark$ & $\checkmark$ & $\checkmark$ & & & & $\checkmark$ & $\checkmark$ & $\checkmark$ \\
\hline SOAS & & & $\checkmark$ & & & 5800 & & 31 & & $\checkmark$ & & & $\checkmark$ & & & $\checkmark$ & $\checkmark$ & \\
\hline St Andrews & & $\checkmark$ & $\checkmark$ & & 1 & 8984 & & 73 & & $\checkmark$ & $\checkmark$ & & & & & $\checkmark$ & & \\
\hline Sussex & $\checkmark$ & $\checkmark$ & $\checkmark$ & & 3 & 19413 & & 51 & UK \#5 & $\checkmark$ & $\checkmark$ & $\checkmark$ & & & & & $\checkmark$ & \\
\hline Swansea & $\checkmark$ & $\checkmark$ & $\checkmark$ & & 2 & 20620 & $\checkmark$ & 9 & & $\checkmark$ & $\checkmark$ & $\checkmark$ & & & & $\checkmark$ & $\checkmark$ & $\checkmark$ \\
\hline UEA & $\checkmark$ & & $\checkmark$ & & 3 & 17925 & $\checkmark$ & 29 & & & $\checkmark$ & $\checkmark$ & $\checkmark$ & & $\checkmark$ & $\checkmark$ & $\checkmark$ & $\checkmark$ \\
\hline Ulster & & $\checkmark$ & $\checkmark$ & & 4 & 24530 & & 57 & & $\checkmark$ & $\checkmark$ & $\checkmark$ & $\checkmark$ & & & $\checkmark$ & $\checkmark$ & $\checkmark$ \\
\hline Westminster & $\checkmark$ & $\checkmark$ & & & 4 & 19000 & & 63 & & & & $\checkmark$ & $\checkmark$ & & & $\checkmark$ & $\checkmark$ & $\checkmark$ \\
\hline
\end{tabular}

Notes: 1) Ancient universities; 2) Redbrick civic universities; 3) 1960s new universities; 4) Post-1992. 
collectively on sustainability with other London universities under the Bloomsbury Greenthing umbrella; the University of Sussex has a large solar farm, while Lancaster has its own wind turbine; and Ulster University has formed a relationship with Belfast City Council to work together on the climate emergency. Furthermore, seven of these institutions signed the global letter declaring a climate emergency and committing to carbon neutrality by 2030, or 2050 at the latest, representing a collective commitment to addressing the climate crisis (SDG Accord, 2021). There are, thus, many interesting and diverse partnerships emerging, as institutions seek to make sense of, and act on, the climate emergency.

The nature of available documents varied between universities; our analysis included 83 documents across the 17 universities. These documents were typically listed on a specific set of webpages dedicated to sustainability. Some universities had a broad overarching strategy for sustainability, whereas others had separate strategies covering topics such as carbon management, food and behaviour change. However, where universities had distinct thematic documents, the topics covered were varied, as Table 1 shows.

We employed discourse analysis to focus on the language and content of university sustainability strategies to reveal the politics and practices of sustainability. As Wilkinson and Clement (2021, p. 12) note, language has power, history, and affects the nature of subsequent responses and actions: Language affects actors differently, reveals ideologies, and enables different kinds of futures. Hatzisavvidou (2020) argues language represents a 'rhetorical invention,' which involves 'devising ways to articulate, define, and constitute relations' between actors and their environments and practices, which leads to the formation of 'a particular environmental common sense.' The 'common sense' she identifies is centred around neoliberalism, which she suggests prevents the possibility of transformative sustainability action. Our analysis employed these methods to uncover the framing and rhetoric of sustainability amongst UK universities. Our secondary analysis involved inductive coding resulting in 40 codes, which emerged from the data in conjunction with concepts from the academic literature. These were then organised into themes, before being organised into higher-level themes. Whilst this remains a relatively small-scale UK study, our analysis was rigorous and thorough in attending to 83 documents produced by our sample, and with both authors coding separately, then reviewing, discussing and refining codes.

\section{Neoliberal Sustainability Practices: University Boosterism and the Cognitive-Practice Gap}

In this section, we contextualise the climate emergency declarations in the UK before outlining how the neoliberalisation of the university sector reduces space for sustainability transformations. We propose a con- cept of university boosterism, whereby universities act extrospectively, employing their sustainability credentials to attract students and funding, and to designate their membership of a global cohort of sustainability leaders. Furthermore, we outline a cognitive-practice gap between university research and university management practices. Together this creates a situation whereby universities are paradoxically sites of transformative research despite practitioners implementing mainstream versions of sustainability.

\subsection{Contextualising Climate Emergency Declarations}

The climate emergency website (climateemergency.uk) details institutions that have currently declared a climate emergency: $74 \%$ of UK local authorities have declared a climate emergency (Mace, 2020), suggesting cross-party commitment to the declarations. The number of universities declaring a climate emergency is lower, with 38 ( $33 \%)$ UK universities having made a declaration at the time of the research. Bristol University was the first UK university to declare a climate emergency (2019), following Bristol City Council (2018). There is an uneven pattern of declaring a climate emergency: Some universities that have not declared a climate emergency refer to other local institutions' declarations, while other universities do not mention the climate emergency.

New governance frameworks and associated organisations are emerging and evolving in response to climate emergency declarations. In October 2020, 72 universities had Sustainability Champions or created sustainability offices, while 117 had produced sustainability strategies. Moreover, a Climate Commission for UK Higher and Further Education Students and Leaders was instigated in November 2019, aiming to develop an action plan in response to the UK government's climate emergency declaration, and to create a strategic sectorwide approach. Alongside the emergence of new institutions, incumbent organisations like the Environmental Association of Universities and Colleges influence universities' sustainability actions through setting policy, sharing best practice, and running the annual Green Gown awards. In addition, organisations like the nongovernmental organisation People and Planet run the 'green league' of UK universities, benchmarking universities based on sustainability criteria. Furthermore, the National Union for Students hosts Students Organising for Sustainability, an educational charity organised by staff and students in response to the ecological and climate crisis, and the University and Colleges Union's Green New Deal agenda (in conjunction with the National Union for Students) "demands that institutions declare a climate emergency" and prepare focused action plans.

Nationally, UK universities are situated within different legislative frameworks of the devolved governments of Scotland, Wales and Northern Ireland, each of which treats sustainable development and climate change 
differently. At the UK level, the Climate Change Act 2008 is perceived as landmark climate legislation (Carter \& Jacobs, 2014); the Scottish government brought forward their Climate Change Act Scotland in 2009. The Welsh government's focus is on sustainable development in the Future Generations and Wellbeing Act 2015, while in Northern Ireland a Private Members' Bill for climate change legislation was presented to government in Autumn 2020.

In sum, this suggests a complex, multi-scalar and relational landscape of sustainability legislation and practice within UK universities and the institutions that support them.

\subsection{Understanding Sustainability}

Sustainability is a slippery term (Blühdorn, 2007), frequently employed to suit the needs of different actors and institutions, and while climate science is unequivocal about the anthropogenic drivers of greenhouse gas emissions, it is less precise about specific outcomes or scenarios (Hulme, 2020). Most universities' sustainability and climate-related strategies recognised the 'wicked' problems of climate change, and specifically human influences on the climate:

Human influence on the world climate is clear, with anthropogenic related carbon emissions the highest in history and warming of the climate system unequivocal. Recent changes in climate have had widespread impacts on human and natural systems and continued emissions will cause further warming and long-lasting changes. This increases the likelihood of severe, pervasive and irreversible impacts for people and ecosystems. (Lancaster University Carbon Management Plan)

We recognise that climate change is one of the most significant global challenges of the century. (Edinburgh University Climate Strategy)

When acknowledging the scale of environmental and climatic problems, universities frequently present themselves as natural leaders with a moral responsibility to act, and as institutions well placed to drive this agenda: "Universities are a major force in creating a more sustainable future, both in the way they conduct their operations and how they build future capacity around sustainable development issues" (Swansea University Sustainability Strategy).

The need to act is accepted but the nature of that action is more contentious (Rosol, Béal, \& Mössner, 2017). Many universities draw on conventional definitions of sustainable development, whereby action is required to ensure "the physical environment remains intact so that human needs can be met" (St Andrews Sustainable Development Policy). Under such definitions, the health of the planet and ecosystems should be pro- tected only for anthropocentric purposes, to sustain economies and societies rather than for the intrinsic value of those ecosystems (Kopnina, 2012), thus treating the environment as valuable only when employed to create surplus value via production.

\subsection{Natural Leaders: Being First and Inspiring Others}

The UK media regularly promotes a limited number of 'exemplar' universities, such as Nottingham Trent University, Manchester Metropolitan and the University of Gloucester. Certification schemes (e.g., EcoCampus, Green Gown awards) are used to promote specific universities' sustainability achievements, while some universities promote their own leadership for others to emulate:

LSE is a global leader in sustainability, not just in terms of its teaching and research on climate change and other environmental issues, but also as a community, a large employer and a business. [It is] an example of best practice that other universities will emulate. (Lord Stern, LSE Sustainability Policy)

Universities' sustainability strategies frequently refer to their desire to be world-leading, world class and adopting leadership positions. Universities, we argue, see themselves as natural sustainability leaders, given their innovative research scoping new intellectual terrain and new forms of technology. Universities argue they are well-placed to address the 'wicked' problem of climate change: "Given the complex and challenging transitions that the pursuit of sustainable development requires, there is an opportunity for the University of St Andrews to play a leadership role in this area within Scotland, the UK and beyond" (St Andrews Sustainable Development Policy).

Best practice is a key method for universities in promoting their own sustainability practices, but they also replicate the actions of others. Best practice can be interpreted as meeting legislative requirements and a common-sense narrative of accepted practice, both of which can limit space for enacting transformative sustainability practices:

We will remain committed to becoming an exemplar of good environmental practice in the [university] sector, in particular around effective carbon reduction. (University of East Anglia [UEA] Environmental Sustainability Policy)

Globally, we are forging links as a member of the International Sustainable Campus Network with leading universities such as Harvard, MIT and Oxford and Cambridge. We are exploring partnerships with leading, European, American, Asian and other global universities to share best practice. (Edinburgh Climate Strategy, emphasis added) 
Institutions such as Oxford, Harvard, Caltech, the University of British Columbia and Yale make up a global cohort of sustainability leaders, viewed as a benchmark for others to follow. Amongst universities, in the UK and more globally, we can identify 'hot' policy ideas (McCann, 2011) coalescing around sustainability activities and initiatives. Peck and Theodore (2015) describe these as 'fast' policies, driven by both the desire for 'ideas that work' and the promotional work of mobile policy experts, gurus and consultants. They argue that 'referencing' ideas from afar is commonplace, and while this is not necessarily new, the speed and intensity of such processes are new. While local expressions of such 'hot' ideas inevitably reflect local circumstances, the idea of flagship green buildings has found rapid traction amongst universities. For instance, Oxford University adopted Passivhaus standards for new buildings in 2017 (Oxford University Sustainability Design Guide). These hot policy ideas are shared and (re)shaped through national and global networks such as the International Sustainable Campus Network and the UK's Sustainability Exchange as well as certification schemes that promote 'best practices.' Such institutions and projects represent what McCann (2017) calls 'referencescapes,' which prioritise some problem framings over others, creating an 'extrospective impulse' that guides what is emulated or not. Furthermore, alongside institutions like Sustainability Exchange, universities act as beacons of best practice and seek to share their sustainability actions via policy mobility circuits. We can identify a global circuit of best practices and sustainability policies for universities, underpinned by a neoliberal agenda that focuses on sustainability as a marketable asset for universities, through the physical (buildings), educational (teaching, curricula, research) and institutional dimensions. Many universities are posturing for global leadership in sustainability and climate responses and structure their strategies around being the 'best':

Our carbon efforts form part of our sector-leading sustainability performance. In 2012, we became the first UK university to achieve the EcoCampus Platinum mark. We were also the first to achieve ISO14001, the international gold standard for environmental management. We have consistently ranked among the top five global universities for sustainability in the UI Green Metric. (Nottingham Trent University Carbon Management Plan)

Rosol et al. (2017) argue that such ranking efforts lead to sustainability losing much of its transformative potential. Certification schemes act discursively to render sustainability practical and technical (Okereke, Bulkeley, \& Schroeder, 2009, p. 76), often aligning to legislation which may generate only modest results. Some universities pursued certification and benchmarking schemes as ends in themselves for reputational purposes, a process we term 'university boosterism':
This Travel Plan will support the University's aspiration to further improve the environmental performance of the University with the ultimate aim of maintaining a top 20 place in the People and Planet league, and a "First Class" award. (Sussex Travel Plan)

Having the platinum status and ISO 14001 certification certainly adds weight to our marketing collateral for attracting new students. They and the wider public are certainly attracted by our green ethos which is why we are fully committed to continual improvement. (NQA Certification, 2014)

Similarly, Queen's University Belfast maintains that they need to be "ahead of the game" (Carbon Management Plan), as students and external partners demand disclosure on their environmental performance. Universities frequently use metrics-based schemes to 'evidence' leadership, for example the Green League published by People and Planet and the EcoCampus certification scheme. The climate emergency declarations potentially reproduce a metrics-driven approach to reach 'zero carbon' by a given date (2030, 2050, etc.; Hulme, 2019). Such techniques facilitate corporate framings of sustainability as improved (eco)efficiency (Freidberg, 2014), which Hatzisavvidou (2020) suggests is regularly witnessed in neoliberal institutions, and which creates quantifiable, measurable policies that are beyond dispute. Hatzisavvidou (2020) identifies three 'commonplaces' of neoliberalism (valuation, efficiency and competitiveness): the use of certification metrics aligns with ideas of efficiency and competitiveness. Furthermore, we might add leadership and 'hot' policy ideas (or 'best practices') to this list of the commonplaces of neoliberalism, representing what it means to be a good neoliberalenvironmental institution.

\subsection{Technology-as-Solution: Efficiencies and Cost-Savings}

Our analysis suggests universities frequently align their climate change responses to technological improvements and cost-savings, representing a capitalist fix by attempting to solve the climate crisis through marketbased instruments, whilst neglecting more ambitious change. This reinforces neoliberal ideologies of efficiency and innovation, for instance Edinburgh University discusses controversial technologies like Carbon Capture and Storage (Perlman, 2020). This involves universities balancing sustainability alongside other considerations, as UEA's Energy and Carbon Strategy exemplifies: "In carbon reduction terms, we work to balance the three sustainable development principles alongside three energyspecific themes: Reputation, capital cost, and operational cost."

The severity of the climate crisis is not (currently) matched with radical action, and universities adopt and reproduce neoliberal responses to climate change. 
Greening contemporary capitalism has more traction for its commercial potential compared to radically transforming operations (Klein, 2014), an approach universities echo:

Mitigation and adaption open up opportunities to apply new technologies, increase efficiency and reduce costs whilst reducing emissions. (Edinburgh Climate Strategy)

The University of Bristol is adopting a Circular Economy approach to managing its resources. This will offer potential cost savings as well as sustainability improvements. (Bristol Circular Economy Strategy)

These statements reinforce how universities embrace techno-fixes. For instance, a key aim of the University of Bristol's Emissions Strategy is: "Achieving financial or operational efficiencies through implementing environmentally sound initiatives." The idea of saving money through efficiency savings is pervasive and frequently based on the adoption of new technologies. Universities like Ulster, Sussex and Lancaster have 'invested' in renewable energies. LSE's focus on improvements in energy performance will increase "energy efficiency in buildings and equipment and minimising carbon emissions by using low and zero carbon technologies wherever possible" (LSE Energy Policy). As Goldstein (2018, p. 17, 30) explains, those involved in cleantech have worked to develop a discourse that is coherent, legitimising and appealing for its apparent radicalism, whilst remaining compatible with capitalism, a new green (and 'better') capitalism, which is anything but transformative. In this vein, Ulster University argues renewable energy will deliver carbon and cost savings: "The University has in place some small-scale photovoltaic generation and a large wind turbine generator. Both technologies are mature, qualify for government subsidies, and can provide significant carbon and cost savings" (Ulster Carbon Management Plan).

Universities are using technology and efficiency gains to capitalise from their climate change practices, and firmly occupying Hatzisavvidou's (2020) 'commonplaces' of neoliberalism. As Blühdorn (2007) argues, relying on technology and market-based solutions reduces environmental issues to concerns about resource consumption and emissions, resolvable via certification and markets, thereby neglecting alternative, more far-reaching policies. This reinforces Chambers' (2020) notion of a 'socio-ecological fix,' whereby environmental problems are solved through a series of capitalist 'fixes' such as new markets or technologies as a response to climate change. For Wakefield (2020, p. 51), promises of such fixes "must be understood as the substrate of a liberal regime promising neither redemption nor progress but only survival of existing, ruinous conditions amidst catastrophe."

\subsection{Cognitive-Practice Gap}

From our analysis, we suggest a cognitive-practice gap exists: While universities are often sites of radical research, this can be disconnected from the types of actions universities-as-institutions propose for responding to climate change. Universities as spaces of research are thus distinct from universities as spaces of sustainability practice. The neoliberalisation agenda means that research questioning dominant modes of consumption and Western lifestyles is often not promoted by universities in their sustainability and climate strategies. As outlined above, the language and ideas within universities' sustainability strategies often adopts and reproduces the hegemony of neoliberalism as governing paradigm (Blythe et al., 2018; Swaffield, 2016). This is important, because as Hall (2016, p. 205) has argued, paradigm shifts cannot materialise unless "people have a language to speak about where they are and what other possible futures are available to them." To bridge this cognitivepractice gap, universities need to create space for dissent and alternative futures to be imagined and experienced. This absence of radical policy and action may be through indifference (Kopnina, 2020), but having declared climate emergencies, indifference will not suffice. As Hoolohan et al. (2021) have recently argued, the climate emergency framing requires institutions to make significant organisational changes to meet the necessary and deep emissions reductions.

To contextualise our findings, we reviewed university research strategies and statements to better understand how universities themselves understand their research activities. Such documents rarely make ideological claims or are explicit about their commitments to a political or economic model, given the breadth of research universities undertake. However, these documents do frequently refer to their world-leading potential and desire to improve their league table rankings: This applies to wider research landscapes as well as sustainability strategies. Fundamentally, these research statements primarily focus on the UK's Research Excellence Framework, being world leading and increasing grant capture.

Some universities (e.g., Bristol, LSE, Westminster) align their research to the UN SDGs, which reproduce mainstream definitions of sustainability: economic prosperity, ecological security and social wellbeing (UN, 2015). The SDGs have been critiqued for promoting an anthropocentric and neoliberal vision, with the environment secondary to economic and social concerns (Hickel, 2019; Kopnina, 2016). The goal of promoting continuous economic growth undermines environmental sustainability objectives, which Kopnina (2016, p. 113) suggests creates a "further objectification of [the] environment and its elements." Aligning objectives to the SDGs suggests that universities are not questioning dominant practices of (over)consumption.

Internationalisation was a common trope within university research statements, with universities aiming 
to attract the best talent, for staff and students, and to facilitate further university student and income growth, attracting students from new and emerging 'markets' (e.g., St Andrews, Cardiff). Internationalisation can undermine sustainability, with international students and international academic conferences contributing to climate change (Baer, 2018; Whitmarsh et al., 2020). The internationalisation agenda leads universities such as St Andrew's to conclude that they cannot 'pick and choose the size of the carbon footprint' despite instituting policies that actively contribute towards this.

As above in relation to sustainability, we identified how university research statements also connect to 'fast' or 'hot' policy ideas, such as Innovation Centres (e.g., Bristol, Cardiff) that connect university research with business to create spin-out companies, based on entrepreneurial logics and a commitment to (economic) growth. About half of our sample specifically include sustainability and climate change as core research priorities (e.g., Bristol, Nottingham Trent, St Andrews, Edinburgh, Sussex, Swansea, Ulster), yet we found no evidence of universities discussing more critical or radical research in these research strategies.

Consequently, these universities both disconnect sustainability discourses developed in research from physical actions implementing sustainability, and conceptualise and implement sustainability and climate initiatives in ways that advance specific forms of green capitalism. As Parr (2013, p. 11) writes, capitalism's actors do not recognise limits to capital accumulation, but rather work to turn these into opportunities to ensure the continuity of economic growth, despite potential for negative impacts on nature and society. For Goldstein (2018) this represents a new form of capital: green capital. This green capital commercialises climate change as (yet) another opportunity for neoliberal economic growth and reproduces unequal power relations whilst (still) not addressing socio-ecological justice (Parr, 2013), maintaining and even expanding resource intensive lifestyles (Goldstein, 2018). Our concern is that the climate emergency declarations may be subject to the same processes of appropriation by capital, where they are employed to promote further economic growth via cleantech and other technological and efficiency driven initiatives. This distracts from the real work of the climate emergency declarations.

\section{Conclusions}

Overall, we suggest universities' neoliberal ideology often leads them to promote sustainability agendas as a form of university boosterism and sustainability capital, rather than attempting more ambitious change. A cognitive-practice gap exists, whereby radical research undertaken within universities is absent in the climate actions they operationalise. As we have discussed, there is potential for the climate emergency declarations to be co-opted by capital, locking in future greenhouse gas emissions growth.
In this article, we have explored the recent climate emergency declarations and have used UK universities' sustainability strategies as a case study for thinking about the possible actions arising from these declarations. Despite a long history of committing to sustainability, universities appear to remain firmly wedded to neoliberal ideals, whilst concurrently claiming to be sites of strong sustainability. Radical changes are not (yet) evident in relation to the climate emergency declarations. Existing sustainability strategies offer insights into the ways of thinking about, and acting on, the climate emergency declarations. Neoliberalism acts as a hegemonic logic to which others must succumb (Swaffield, 2016), which may limit the emergence of more radical change following the climate emergency declarations. Without such change, it is unlikely that the current, unsustainable paradigm will be transformed (cf. Bina, 2013). This represents a missed opportunity for universities to create a bridge between critical research and their sustainability practices, which could be addressed in their climate emergency plans and thus simultaneously contribute to wider societal goals. As Malm (2018) suggests, the climate crisis lays the conditions for a possible revolution against the continued reproduction of capitalism: To what extent can universities help enact this revolutionary future? Universities would need to promote a global transformation engendering Wals' (2010, p. 150) "planetary consciousness."

This study remains limited to the UK, and more research is needed to examine whether these findings apply in different spatial contexts and under different political economic systems. Further research is needed to understand the institutional complexities of new organisations and governance processes emerging following the declarations, and how those working in such organisations and roles understand this work. The appointment of new staff in universities and local government in response to the climate emergency declarations provides fertile ground for exploring these ideas, both in the UK and internationally. Furthermore, research could helpfully explore the alternative narratives that remain unheard. The dialogue that does not happen may be as important as that which is heard, seen and publicised: Narratives framed around green growth make other solutions less tenable. We particularly note that universities' sustainability and carbon management plans place innovation centre stage and pay little attention to concepts such as degrowth. At present, universities are not utilising the findings from critical social science research which leaves a gap between critical sustainability research and practice. Given the severity of the climate crisis, universities could reposition their sustainability strategies to create pathways to degrowth, rather than reproducing capitalist fixes such as technology-as-solution.

\section{Acknowledgments}

We are grateful to the anonymous reviewers whose comments have helped improve this article immeasurably. 
We would also like to thank the Academic Editors of the thematic issue for their constructive comments and advice, as well as the editors at Cogitatio for support and smooth processing. Thanks to Helen Coulson for comments on an earlier draft. All errors remain our own.

\section{Conflict of Interests}

The authors declare no conflict of interests.

\section{References}

Anderson, B., Grove, K., Rickards, L., \& Kearnes, M. (2020). Slow emergencies: Temporality and the racialized biopolitics of emergency governance. Progress in Human Geography, 44(4), 621-639.

Baer, H. A. (2018). Grappling with flying as a driver to climate change: Strategies for critical scholars seeking to contribute to a socio-ecological revolution. The Australian Journal of Anthropology, 29, 298-315.

Bergland, B. (2018). The incompatibility of neoliberal university structures and interdisciplinary knowledge: A feminist slow scholarship critique. Educational Philosophy and Theory, 50(11), 1031-1036.

Bina, O. (2013). The green economy and sustainable development: An uneasy balance? Environment and Planning C: Government and Policy, 31(6), 1023-1047.

Blühdorn, I. (2007). Sustaining the unsustainable: Symbolic politics and the politics of simulation. Environmental Politics, 16(2), 251-275.

Blythe, J., Silver, J., Evans, L., Armitage, D., Bennett, N. J., Moore, M. L., . . Brown, K. (2018). The dark side of transformation: Latent risks in contemporary sustainability discourse. Antipode, 50(5), 1206-1223.

Buck, H. J. (2015). On the possibilities of a charming Anthropocene. Annals of the Association of American Geographers, 105(2), 369-377.

Bulletin of the Atomic Scientists. (2020). Closer than ever: It is 100 seconds to midnight: 2020 doomsday clock statement. Bulletin of the Atomic Scientists. Retrieved from https://thebulletin.org/doomsdayclock/current-time

Carter, N., \& Jacobs, M. (2014). Explaining radical policy change: The case of climate change and energy policy under the British Labour government 2006-10. Public Administration, 92(1), 125-141.

Castree, N. (2015). Geography and global change science: Relationships necessary, absent, and possible. Geographical Research, 53, 1-15.

Chambers, C. (2020). A critique of the 'socio-ecological fix' and towards revolutionary rupture. Area, 53(1), 1-8. https://doi.org/10.1111/area.12668

Ciplet, D., \& Roberts, J. (2017). Climate change and the transition to neoliberal environmental governance. Global Environmental Change, 46, 148-156.

Cohen, D. (2020). Confronting the urban climate emergency: Critical urban studies in the age of a green new deal. City, 24(1/2), 52-64.

Croog, R. (2016). Campus sustainability at the edges: Emotions, relations, and bio-cultural relations. Geoforum, 74, 108-116.

Crutzen, P., \& Schwägerl, C. (2011). Living in the Anthropocene: Toward a new global ethos. Yale Environment 360. Retrieved from https://e360.yale. edu/features/living_in_the_anthropocene_toward_ a_new_global_ethos

Cupples, J. (2012). Boundary crossings and new striations: When disaster hits a neoliberalising campus. Transactions of the Institute of British Geographers, 37(3), 337-341.

Cupples, J., \& Pawson, E. (2012). Giving an account of oneself: The PBRF and the neoliberal university. New Zealand Geographer, 68(1), 14-23.

Dalby, S. (2019). Bordering sustainability in the Anthropocene. Territory, Politics, Governance, 8(2), 144-160.

Disterheft, A., Caeiro, S., Azeiteiro, U. M., \& Leal Filho, W. (2013). Sustainability science and education for sustainable development in universities: A way for transition. In S. Caeiro, W. Leal Filho, U. Azeiteiro, \& C. Jabbour (Eds.), Sustainability assessment tools in higher education institutions (pp. 3-27). Cham: Springer.

Dobson, J. (2019). Reinterpreting urban institutions for sustainability: How epistemic networks shape knowledge and logics. Environmental Science and Policy, 92, 133-140.

Feola, G. (2020). Capitalism in sustainability transitions research: Time for a critical turn? Environmental Innovations and Societal Transitions, 35, 241-250.

Freidberg, S. (2014). Footprint technopolitics. Geoforum, $55,178-189$.

Gibbs, L. (in press). Animal geographies II: Killing and caring (in times of crisis). Progress in Human Geography.

Gills, B., \& Morgan, J. (2020). Global climate emergency: After COP24, climate science, urgency, and the threat to humanity. Globalizations, 17(6), 885-902.

Goh, K. (2019). Urban waterscapes: The hydro-politics of flooding in a Sinking City. International Journal of Urban and Regional Research, 43(2), 250-272.

Goldstein, J. (2018). Planetary improvement: Cleantech entrepreneurship and the contradictions of green capitalism. Boston, MA: MIT Press.

Gormally, A., O’Neill, K., Hazas, M., Bates, O., \& Friday, A. (2019). 'Doing good science': The impact of invisible energy policies on energy demand in higher education. Energy Research and Social Science, 52, 123-131.

Hall, S. (2016). Cultural studies 1983: A theoretical history. Durham, NC and London: Duke University Press.

Hatzisavvidou, S. (2020). Inventing the environmental state: Neoliberal common sense and the limits to transformation. Environmental Politics, 29(1), 96-114.

Hickel, J. (2019). The contradiction of the Sustainable Development Goals: Growth vs ecology on a finite 
planet. Sustainable Development, 27(5), 873-884.

Hoolohan, C., McLachlan, C., Jones, C., Larkin, A., Birch, C., Mander, S., \& Broderick, J. (2021). Responding to the climate emergency: How are UK universities establishing sustainable workplace routines for flying and food? Climate Policy. https://doi.org/10.1080/ 14693062.2021.1881426

Huijbens, E. H. (2021). The emerging earths of climatic emergencies: On the island geography of life in modernity's ruins. Geografiska Annaler. https://doi. org/10.1080/04353684.2021.1873072

Hulme, M. (2019). Climate emergency politics is dangerous. Issues in Science and Technology, 36(1), 23-25.

Hulme, M. (2020). Is it too late (to stop dangerous climate change)? An editorial. Wiley Interdisciplinary Reviews: Climate Change, 11(1). https://doi.org/ 10.1002/wcc.619

Jackson, M. (2020). On decolonizing the Anthropocene: Disobedience via plural constitutions. Annals of the American Association of Geographers. https://doi. org/10.1080/24694452.2020.1779645

Jänicke, M. (2008). Ecological modernisation: New perspectives. Journal of Cleaner Production, 16(5), 557-565.

Klein, N. (2014). This changes everything: Capitalism vs the climate. New York, NY: Penguin.

Kopnina, H. (2012). Education for sustainable development (ESD): The turn away from 'environment' in environmental education? Environmental Education Research, 18(5), 699-717.

Kopnina, H. (2016). The victims of unsustainability: A challenge to sustainable development goals. International Journal of Sustainable Development \& World Ecology, 23(2), 113-121.

Kopnina, H. (2020). Education for the future? Critical evaluation of education for sustainable development goals. The Journal of Environmental Education, 51(4), 280-291.

Lightfoot, L. (2019, July 16). University green rankings at risk despite climate emergency. The Guardian. Retrieved from https://www.theguardian. com/education/2019/jul/16/university-greenrankins-risk-despite-climate-emergency

Lozano, R. (2006). Incorporation and institutionalization of SD into universities: Breaking through barriers to change. Journal of Cleaner Production, 14(9), 787-796.

Mace, M. (2020). Majority of local authorities have declared climate emergencies. Edie Net. Retrieved from https://www.edie.net/news/9/Majority-oflocal-authorities-have-declared-climateemergencies/?utm_source=dailynewsletter,\%20 edie\%20daily\%20newsletter\&utm_medium=email, \%20email\&utm_content=news\&utm_campaign= dailynewsletter,\%205ff6a44416-dailynewsletter_ COPY_929

Madden, D. (2019). Editorial: City of emergency. City, 23(3), 281-284.
Malm, A. (2018, March 17). Revolutionary strategy in a changing world. Climate and Capitalism. Retrieved from https://climateandcapitalism.com/2018/03/ 17/malm-revolutionary-strategy

McCann, E. (2011). Urban policy mobilities and global circuits of knowledge: Toward a research agenda. Annals of the American Association of Geographers, 101(1), 107-130.

McCann, E. (2017). Mobilities, politics, and the future: Critical geographies of green urbanism. Environment and Planning A, 49(8), 1816-1823.

NQA Certification. (2014). NTU case study. NQA. Retrieved from https://www.nqa.com/en-gb/ resources/case-studies/ntu

Okereke, C., Bulkeley, H., \& Schroeder, H. (2009). Conceptualizing climate governance beyond the international regime. Global Environmental Politics, 9(1), 58-78.

Osborne, N. (2019). For still possible cities: A politics of failure for the politically depressed. Australian Geographer, 50(2), 145-154.

Parr, A. (2013). The wrath of capital: Neoliberalism and climate change politics. New York, NY: Columbia University Press.

Peck, J., \& Theodore, N. (2015). Fast policy. Minneapolis, MN: University of Minnesota Press.

Perlman, K. (2020). BECCS: No time for false saviours. One Earth. Retrieved from https://www.oneearth. org/beccs-no-time-for-false-saviours

Ramísio, P. J., Pinto, L. M. C., Gouveia, N., Costa, H., \& Arezes, D. (2019). Sustainability strategy in higher education institutions: Lessons learned from a nineyear case study. Journal of Cleaner Production, 222, 300-309.

Renouf, J. S., Mann, M. E., Cook, J., Wright, C., Steffen, W., Nunn, P., . . . Richardson, A. P. K. (2019, September 27). Why universities need to declare an ecological and climate emergency. Times Higher Education. Retrieved from https://www.times highereducation.com/blog/why-universities-needdeclare-ecological-and-climate-emergency

Rosol, M., Béal, V., \& Mössner, S. (2017). Greenest cities? The (post-)politics of new urban environmental regimes. Environment and Planning A, 49(8), 1710-1718.

SDG Accord. (2021). Global climate letter for universities and colleges. SDG Accord. Retrieved from https:// www.sdgaccord.org/climateletter

Slaughter, S., \& Leslie, L. L. (1997). Academic capitalism: Politics, policies, and the entrepreneurial university. Baltimore, MD: John Hopkins University Press.

Swaffield, J. (2016). After a decade of critique: Neoliberal environmentalism, discourse analysis and the promotion of climate-protecting behaviour in the workplace. Geoforum, 70, 119-129.

Thunberg, G. (2020). Open letter from Greta Thunberg: \#facetheclimateemergency. Climate Emergency Declaration. Retrieved from https://climate 
emergencydeclaration.org/open-letter-from-greta-

thunberg-facetheclimateemergency

UNEP. (2018). Emissions gap report 2018 (9th ed.). New York, NY: UNEP.

United Nations. (2015). Sustainable Development Goals. United Nations. Retrieved from https://sdgs.un.org/ goals

Wadud, Z., Royston, S., \& Selby, J. (2019). Modelling energy demand from higher education institutions: $A$ case study of the UK. Applied Energy, 233, 816-826.

Wakefield, S. (2020). Anthropocene back loop: Experimentation in unsafe operating space. London: Open University Press.

Wals, A. E. J. (2010). Between knowing what is right and knowing that is it wrong to tell others what is right: On relativism, uncertainty and democracy in environmental and sustainability education. Environmental
Education Research, 16(1), 143-151.

Whitmarsh, L., Capstick, S., Moore, I., Jana, K., \& Qu, C. (2020). Use of aviation by climate change researchers: Structural influences, personal attitudes, and information provision. Global Environmental Change, 65. https://doi.org/10.1016/ j.gloenvcha.2020.102184

Whyte, K. P. (2020). Too late for Indigenous climate justice: Ecological and relational tipping points. WIRES Climate Change, 11, 1-7.

Wilkinson, C., \& Clement, S. (2021). Geographers declare (a climate emergency)? Australian Geographer. https://doi.org/10.1080/00049182.2020.1866278

Wright, C., Nyberg, D., Rickards, L., \& Freund, J. (2018). Organizing in the Anthropocene. Organization, 25(4), 455-471.

\section{About the Authors}

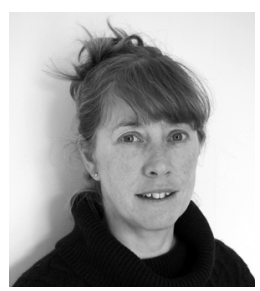

Kirstie O'Neill is a Lecturer in Environmental Geography at Cardiff University (UK) in the School of Geography and Planning. Kirstie's research focuses on environmental governance and sustainability transitions, specifically relating to green economies, green building and food sustainability. She is particularly interested in emerging climate emergency governance and the potential for transformative sustainability.

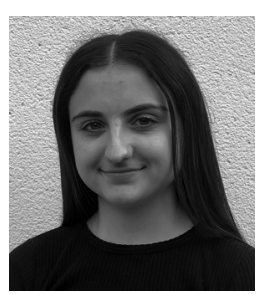

Charlotte Sinden is a Postgraduate Researcher at Cardiff University (UK) in the School of Geography and Planning. Charlotte's research focuses on sustainability in the higher education context and sustainability transitions, with a particular interest in exploring how institutions are tackling the climate emergency. 